DOI: $10.15290 /$ bsp.2017.22.01.01

Cezary Kulesza

Uniwersytet w Białymstoku

c_kulesza@wp.pl

\title{
Ewolucja wybranych procedur dyscyplinarnych w świetle konwencyjnego i konstytucyjnego standardu prawa do sądu ${ }^{1}$
}

\section{Evolution of the models of disciplinary procedures in the light of conventionaland con- stitutional standards of the right to court}

\begin{abstract}
The article focuses on the evolution of one of the most vital elements of disciplinary proceedings, that being court control over disciplinary decisions. Regarding this issue the article discusses the jurisprudence of the European Court of Human Rights and the Polish Constitutional Tribunal. Presented historical and functional analysis of model disciplinary proceedings across many different professions, leads to distinction in the basic restrictions of the right to court and their character in disciplinary proceedings. With reference to appealing against the decisions of disciplinary bodies, the article makes it noticeable that the lines between civil and penal procedures are blurred. Finally, the article addresses the influence amendments being made in Polish penal procedure and the Act on Prosecution in the years 2015-2016, are having on the application of disciplinary proceedings.
\end{abstract}

Keywords: models, disciplinary proceedings, judicial control, Supreme Court, ECHR

Słowa kluczowe: modele, postępowanie dyscyplinarne, sądowa kontrola, Sąd Najwyższy, ETPCz

\section{Uwagi wstępne}

Do podstawowych elementów modeli postępowania dyscyplinarnego można zaliczyć:

1 Niniejszy artykuł powstał w ramach projektu badawczego pt. „Czy polski model postępowania odwoławczego w sprawach karnych jest rzetelny?” (konkurs „OPUS 8”) finansowanego przez Narodowe Centrum Nauki zgodnie z umową nr UMO-2014/15/B/HS5/02689. 
1) funkcje pełnione przez to postępowanie²: represyjną, gwarancyjną (ochronną) i integracyjną;

2) materialnoprawne podstawy odpowiedzialności dyscyplinarnej;

3) organy postępowania i stosowane przez nie procedury (w szczególności zakres stosowania w nich przepisów kpk.);

4) sądową kontrolę orzeczeń sądów dyscyplinarnych.

W świetle literatury przedmiotu nie budzi wątpliwości pogląd, że prawo dyscyplinarne ma ścisłe związki z prawem karnym (niekiedy też z prawem administracyjnym) i można je zaliczyć do szeroko rozumianego prawa represyjnego ${ }^{4}$. Prawo dyscyplinarne od prawa karnego odróżniają jednak stosowane przez nie sankcje, a także brak powszechnego obowiązywania, gdyż odnosi się ono jedynie do określonych grup zawodowych. Jak wskazuje się m.in. w orzecznictwie TK, funkcja ta polega na zapewnieniu członkom korporacji należytej swobody i niezależności przy wykonywaniu zawodu. Trybunał dostrzegał również $\mathrm{w}$ swoim orzecznictwie odmienną rolę sądów w sprawach, które dotyczyły postępowań dyscyplinarnych wobec osób wykonujących zawód zaufania publicznego oraz w sprawach, w których odpowiedzialność dyscyplinarna egzekwowana była wobec osób wykonujących inny zawód. $\mathrm{O}$ ile w tym ostatnim wypadku kontrola sądów nad orzecznictwem dyscyplinarnym stanowi gwarancję ochrony konstytucyjnych praw i wolności osób ukaranych, o tyle $\mathrm{w}$ pierwszym wypadku pełni ona dwie równorzędne funkcje. $Z$ jednej strony zapewnia członkom samorządu zawodowego niezbędną swobodę i niezależność przy wykonywaniu zawodu, $\mathrm{z}$ drugiej zaś - stanowi instrument nadzoru państwa nad samorządami zawodowymi ${ }^{5}$.

Wydaje się, że w przeciwieństwie do prawa karnego nie można przypisać prawu dyscyplinarnemu pełnienia funkcji kompensacyjnej. W procedurach dyscyplinarnych co do zasady mogą występować pokrzywdzeni, lecz procedury te nie przewidują żadnych form zaspokojenia cywilnoprawnych roszczeń pokrzywdzonym przez delikty dyscyplinarne.

Warto wskazać, że uniwersalną podstawą odpowiedzialności dyscyplinarnej we wszystkich grupach zawodowych jest naruszenie zasad etyki i godności zawodu. W przypadku postępowania dyscyplinarnego wobec prokuratorów wypada dostrzec orzeczenie Sądu Najwyższego odnoszące się do uchybienia przez prokuratora (który w trakcie mowy obrończej czytał na sali sądowej książkę) godności urzędu jako podstawy odpowiedzialności dyscyplinarnej: „Godność urzędu prokuratorskiego rozu-

2 P. Skuczyński, Aktualne problemy odpowiedzialności dyscyplinarnej w zawodach prawniczych, (w:) Postępowania dyscyplinarne w zawodach prawniczych. Model ustrojowy i praktyka, A. Bodnar, P. Kubaszewski (red.), Warszawa 2013, s. 65-67.

3 P. Skuczyński, Aktualne problemy odpowiedzialności dyscyplinarnej w zawodach prawniczych, s. 60-64.

$4 \quad$ K. Dudka, Stosowanie przepisów k.p.k. w postępowaniu dyscyplinarnym w stosunku do nauczycieli akademickich (w:) Węzłowe problemy procesu karnego, P. Hofmański (red.), Warszawa 2010, s. 354-355. Zob. także wyrok SN z dnia 23 września 2016 r., SDI 44/16, http://www.sn.pl/orzecznictwo (data dostępu: 23.11.2016 r.). Zob. wyrok TK z dnia 8 grudnia 1998 r., K 41/97, OTK 1998, nr 7, poz. 117. 
Ewolucja wybranych procedur dyscyplinarnych w świetle konwencyjnego...

miana być zatem powinna jako pewien standard zachowania w różnych służbowych i pozasłużbowych okolicznościach, standard formułujący wobec prokuratorów podwyższone wymagania powodujące, że powinni oni stanowić rodzaj wzorca dla innych osób uczestniczących w czynnościach służbowych"6.

W aspekcie podstaw odpowiedzialności dyscyplinarnej sędziów warto wskazać na ciekawy wyrok Sądu Najwyższego odnoszący się do granic zasady niezawisłości sędziowskiej, przyjmujący, że „(...) gwarantowana w Konstytucji niezawisłość sędziowska nie ma charakteru absolutnego w tym znaczeniu, że pozwala na każdą dowolną interpretację prawa i jego stosowanie przez sędziego. Przyjęcie założenia o tak rozumianej niezawisłości doprowadziłoby do stworzenia systemu całkowitej dowolności orzekania, bez poczucia stabilności i pewności prawa, przewidywalności czynności sądu, a w skrajnym przypadku do anarchii. Prawo sędziego do własnej, samodzielnej interpretacji przepisów nie daje sędziemu podstaw do dowolnego kształtowania ich treści i nie uwalnia go od refleksji w razie stwierdzenia, że stosowana przez niego wykładnia odbiega od jednolitej wykładni dokonywanej przez Sąd Najwyższy lub sąd odwoławczy (...)"7.

W niniejszym opracowaniu skoncentrujemy się właśnie na ewolucji prawa obwinionych do zaskarżenia orzeczeń sądów dyscyplinarnych do sądów powszechnych bądź do Sądu Najwyższego, jako gwarancji sprawiedliwości proceduralnej i materialnej.

\section{Konwencyjny standard sądowej kontroli postępowań dyscyplinarnych}

Podstawowe znaczenie dla zdefiniowania konwencyjnego standardu prawa do sądu ma artykuł 6 ust. 1 Europejskiej Konwencji Praw Człowieka stanowiący w zdaniu pierwszym: „Każdy ma prawo do sprawiedliwego i publicznego rozpatrzenia jego sprawy w rozsądnym terminie przez niezawisły i bezstronny sąd ustanowiony ustawą przy rozstrzyganiu o jego prawach i obowiązkach o charakterze cywilnym albo o zasadności każdego oskarżenia w wytoczonej przeciwko niemu sprawie karnej”.

Natomiast w przypadku standardu konstytucyjnego kryterium oceny rzetelności procedur dyscyplinarnych należy upatrywać przede wszystkim w regulacji art. 45 ust. 1 Konstytucji stanowiącego, że każdy ma prawo do sprawiedliwego i jawnego rozpatrzenia sprawy bez nieuzasadnionej zwłoki przez właściwy, niezależny, bezstronny i niezawisły sąd.

W świetle orzecznictwa ETPCz uprawniony jest generalny wniosek, że nie narusza standardu konwencyjnego orzekanie w sprawach dyscyplinarnych przez organy niespełniające wymogu „niezawisłego i bezstronnego sądu”.

6 Postanowienie SN z dnia 27 lipca 2016, SDI 6/16, http://www.sn.pl/orzecznictwo (data dostępu: 23.11.2016 r.).

$7 \quad$ Wyrok SN z dnia 16 czerwca 2016 r., SNO 21/16, Lex nr 2064239.

8 Tak w przypadku sądów dyscyplinarnych; Le Compte, Van Leven i De Meyere przeciwko Belgii z dnia 23 czerwca 1981 r., skargi nr 6878/75; 7238/75); Frankowicz przeciwko Polsce z dnia 16 grudnia 2008 r. (skarga nr 53025/99) 
Ciekawym przykładem jest tu chociażby orzeczenie ETPCz z dnia 27 stycznia 2004 r. w sprawie Kyprianou v. Cyprus (skarga 73797), w którym Trybunał orzekł, że brak jest bezstronności sądu pierwszej instancji, który nałożył na skarżącego karę pozbawienia wolności za popełnienie przestępstwa obrazy sądu (contempt of court). W sprawie tej uznano, że groźba ukarania taką karą obrońcy może wbijać „zimny klin" (chilling edge) w efektywną obronę sprawowaną przez adwokata. Również w wyroku z dnia 15 grudnia 2005 r. w tej samej sprawie Wielka Izba ETPCz, która mimo iż doszła do tego samego wniosku, skupiła się raczej na tym, że Sąd Najwyższy nie uchylił orzeczenia sądu niższej instancji, chociaż był do tego uprawniony. Brak bezstronności nie został naprawiony przez Sąd Najwyższy w postępowaniu odwoławczym, ponieważ sąd ten nie przystąpił do ponownego rozpoznania sprawy.

\section{Konstytucyjny standard sądowej kontroli postępowań dyscyplinarnych}

Zgodnie z utrwalonym orzecznictwem Trybunału Konstytucyjnego w obowiązującym porządku prawnym dopuszczalne jest działanie innych niż sądy państwowe organów utworzonych w celu rozstrzygania sporów o prawa, w tym sądów dyscyplinarnych tworzonych w ramach korporacyjnych struktur organizacyjnych.

$\mathrm{Na}$ tle art. 45 ust. 1 Konstytucji Trybunał Konstytucyjny przyjmował wielokrotnie, np. w wyroku z dnia 11 września 2001 r. ${ }^{9}$, że gwarancją poszanowania praw i wolności obwinionego jest zapewnienie kontroli sądowej orzeczeń w sprawach dyscyplinarnych. „We wszystkich postępowaniach o charakterze represyjnym prawo do sądu pełni rolę szczególną, gwarantującą kontrolę poszanowania praw i wolności obywatelskich przez niezależny, bezstronny i niezawisły sąd" ${ }^{10}$. Podkreślając, że postępowanie kontrolne sądu ze swej natury musi mieć charakter ograniczony, gdyż kontrola nie polega na rozstrzyganiu spraw od podstaw, Trybunał wskazywał jednocześnie na rzeczywistość i efektywność prawa do sądu w postępowaniach dyscyplinarnych i zauważał, że: „(..) prawo do sądu jest zachowane na gruncie takich regulacji, które zapewniają kontrolę sądową rozstrzygnięcia, decyzji czy innego aktu indywidualnego kształtującego sytuację prawną podmiotu - poprzez uruchomienie postępowania przed sądem powszechnym lub sądem administracyjnym"11.

Trybunał Konstytucyjny dostrzegał jednocześnie, że w polskim systemie prawnym odpowiedzialność dyscyplinarna dotyczy wielu grup zawodowych, jednak nie

oraz w wyroku z 18 października 2011 r. w sprawie Sosinowska przeciwko Polsce (skarga nr 10247/09). Zob. analizę tego wyroku, (w:) A. Bodnar, Postępowania dyscyplinarne w wolnych zawodach prawniczych w kontekście orzecznictwa ETPC (w:) Postępowania dyscyplinarne w zawodach prawniczych, s. 23-24.

$9 \quad$ SK 17/2000, Dz.U. z 2001 r. poz. 1129.

10 Zob. także wyrok TK z dnia 19 maja 2003 r., K. 39/2003 r., OTK-A 2005, nr 3, poz. 27 oraz powołane tam orzecznictwo.

11 Wyrok TK z dnia 4 marca 2008 r., SK 3/07, OTK-A 2008, nr 2, poz. 25; zob. także wyrok TK z dnia 17 listopada 2009 r., SK 64/08, Lex, OTK-A 2009, nr 10, poz. 148. 
Ewolucja wybranych procedur dyscyplinarnych w świetle konwencyjnego...

przewidziano w nim jednolitej procedury znajdującej zastosowanie do ustalania tej odpowiedzialności w wypadku wszystkich zawodów, w tym również zawodów prawniczych $^{12}$.

\section{Ewolucja modeli postępowania dyscyplinarnego w kontekście prawa do sądu}

Dokonując analizy historycznej i funkcjonalnej modeli postępowania dyscyplinarnego w różnych korporacjach zawodowych, można generalnie stwierdzić, że podstawowe ograniczenia prawa do sądu miały charakter:

1) podmiotowy (ograniczenia kręgu podmiotów uprawnionych do zaskarżenia orzeczeń organów dyscyplinarnych do sądu);

2) przedmiotowy (ograniczenia rodzaju spraw, w których przysługiwał środek zaskarżenia do sądu) - orzeczenie nieprawomocne bądź prawomocne;

3) rodzaju środka zaskarżenia i związanego z nim zakresu kognicji rozpoznającego go sądu działającego jako instancja odwoławcza.

Wszystkie te ograniczenia, występujące w różnych konfiguracjach, podlegały stopniowej ewolucji, ściśle skorelowanej ze zmianami powszechnej procedury karnej oraz konieczności dostosowania procedur dyscyplinarnych do Konstytucji z 1997 r.

Odnosząc te uwagi do zawodów prawniczych, można wskazać na ustawę Prawo o adwokaturze $z$ dnia 26 maja 1982 r. (dalej jako p.a.) ${ }^{13}$, która w pierwotnym brzmieniu przyznawała prawo do wniesienia rewizji nadzwyczajnej od prawomocnego orzeczenia sądu dyscyplinarnego jedynie podmiotom szczególnym (Ministrowi Sprawiedliwości, Prokuratorowi i Prezesowi NRA - art. 91 ust. 1 p.a.). Ustawa o radcach prawnych z 6 lipca $1982 \mathrm{r}^{14}$. w pierwotnym brzmieniu przewidywała także $\mathrm{w}$ art. 65 ust. 3 ograniczenie przedmiotowe, stanowiąc, że jedynie od orzeczenia dyscyplinarnego orzekającego karę zawieszenia lub pozbawienia prawa do wykonywania zawodu (ale nie od upomnienia) ukaranemu przysługuje prawo wniesienia odwołania do Sądu Najwyższego. Natomiast ustawa o prokuraturze z dnia 20 czerwca 1985 r. $\mathrm{w}$ pierwotnym brzmieniu ${ }^{15}$ nie przewidywała sądowej kontroli orzeczeń wydawanych w postępowaniach dyscyplinarnych.

Modele sądowej kontroli postępowań dyscyplinarnych w tych korporacjach zostały ujednolicone regulacjami odpowiednich ustaw z 2000 r. przez wprowadzenie instytucji „rozszerzonej” kasacji do Sądu Najwyższego, która może być oparta zarówno na podstawach „rażącego naruszenia prawa”, jak i „rażącej niewspółmierności kary dyscyplinarnej”. Regulacje te zostały uznane za zgodne $\mathrm{z}$ art. 45 ust. 1 Konstytucji

Wyrok TK z dnia 25 czerwca 2012 r., K. 9/2010, OTK ZU 2012/6A poz. 66.

Ustawa z dnia 26 maja 1982 r. Prawo o adwokaturze (tekst jedn. z dnia 6 maja 2015, Dz.U. z 2015 r. poz. 615).

Ustawa z dnia 6 lipca 1982 r. o radcach prawnych (tekst jedn. z dnia 25 marca 2016, Dz.U. z 2016 r. poz. 233).

Ustawa z dnia 20 czerwca 1985 r. Prawo o prokuraturze (Dz.U. z 1985 r. Nr 31, poz. 138 ze zm.). 
RP w powołanym wcześniej wyroku Trybunału Konstytucyjnego z dnia 25 czerwca $2012 \mathrm{r}^{16}$. Warto jednak zauważyć, że pojęcie rażącej niewspółmierności kary dyscyplinarnej jako podstawy kasacji jest w orzecznictwie SN traktowane dość restryktywnie, gdyż, jak stwierdza się w nim, stosowanie unormowań Kodeksu karnego w tym zakresie byłoby niemożliwe $\mathrm{z}$ uwagi na specyfikę kar dyscyplinarnych i innych środków reakcji na przewinienie dyscyplinarne, określonych w art. 81 u.p.a., tj. zwłaszcza ze względu na ich nieterminowy charakter w większości przypadków ${ }^{17}$.

W przypadku ustawy o adwokaturze (i odpowiednio ustawy o radcach prawnych) aktualność stracił pogląd Sądu Najwyższego wyrażony w postanowieniu z dnia 27 września $2012 \mathrm{r}^{18}$. Zgodnie $\mathrm{z}$ nim obwiniony adwokat nie może wnieść kasacji od wyroku Wyższego Sądu Dyscyplinarnego wydanego w jego sprawie, gdyż stanowiłoby to obejście wymogu przewidzianego $\mathrm{w}$ art. $526 \$ 2 \mathrm{kpk}^{19}$. Zgodnie bowiem $\mathrm{z}$ wyrokiem Trybunału Konstytucyjnego ${ }^{20}$, zapadłym w kontekście postępowania dyscyplinarnego prowadzonego wobec adwokata, art. $526 \$ 2$ kpk., w zakresie w jakim wyłącza możliwość sporządzenia i podpisania kasacji we własnej sprawie przez adwokata bądź radcę prawnego, jest niezgodny z art. 45 ust. 1 Konstytucji Rzeczypospolitej Polskiej.

W aktualnym orzecznictwie Sądu Najwyższego dotyczącym postępowania dyscyplinarnego wobec adwokatów wskazuje się, że jest ono zbliżone do postępowania karnego, a ustawodawca uznał, że w jego toku powinny obowiązywać standardy i gwarancje podobne lub identyczne $\mathrm{z}$ funkcjonującymi w postępowaniach karnych. Zdaniem Sądu Najwyższego oznacza to między innymi, że obwiniony korzysta z rozwiązań procesowych zapewniających mu realizację prawa do obrony, a w samym postępowaniu obowiązuje zasada bezpośredniości ${ }^{21}$.

Warto również wskazać na najnowsze orzecznictwo Sądu Najwyższego odnoszące się do postępowania dyscyplinarnego wobec radców prawnych. Przyjęto w nim słusznie, że przed Wyższym Sądem Dyscyplinarnym Krajowej Izby Radców Prawnych obowiązuje zakaz ne peius określony w art. $454 \$ 1 \mathrm{kpk}$. i zabrania sądowi dyscyplinarnemu skazywania w instancji odwoławczej obwinionego radcy, który został uniewinniony w pierwszej instancji ${ }^{22}$.

$\mathrm{Na}$ istotne związki pomiędzy procedurą karną a postępowaniami dyscyplinarnymi wskazywano wielokrotnie $\mathrm{w}$ orzecznictwie Sądu Najwyższego ${ }^{23}$.W uchwale

K. 9/2010, OTK ZU 2012/6A poz. 66.

Postanowienie SN z dnia 17 listopada 2015 r., SDI 67/15, Lex nr 1849091.

VI KZ 12/12, Lex nr 122100.

Zob. także postanowienie SN dotyczące sprawy karnej prowadzonej przez adwokata jako oskarżyciela prywatnego z dnia 15 czerwca 2016 r., II KZ 16/16, Lex nr 2054092. Ten pogląd SN był zasadniczo zbieżny z poglądami komentatorów przepisów o postępowaniu dyscyplinarnym adwokatów. Zob. K. Kanty, T. Kanty, Komentarz do przepisów o postępowaniu dyscyplinarnym adwokatów, Warszawa - Gdańsk 2013, s. 234-235.

SK 2/15, OTK-A 2016.

Wyrok SN z dnia 27 lipca 2016 r., SDI 28/16.

Wyrok SN z dnia 23 września 2016 r., SDI 44/16, , http://www.sn.pl/orzecznictwo- dostęp z 23 listopada 2016 r.

Zob. W. Kozielewicz, Postępowania dyscyplinarne w wolnych zawodach prawniczych w praktyce orzeczniczej SN (w:) Postępowania dyscyplinarne..., s. 39-45 oraz tenże w niniejszej publikacji: Rola Sądu Najwyższego w postępowaniu w sprawach dyscyplinarnych. 
Ewolucja wybranych procedur dyscyplinarnych w świetle konwencyjnego...

Składu Siedmiu Sędziów z dnia 28 września 2006 r²4. Sąd Najwyższy przyjął, iż postępowanie dyscyplinarne toczy się niezależnie od postępowania karnego, także w przypadku tożsamości przedmiotowo-podmiotowej tych postępowań. Sądy dyscyplinarne powinny jednak zawiesić postępowanie dyscyplinarne do zakończenia postępowania karnego, gdy zachodzi konieczność zastosowania art. $108 \$ 4$ ustawy o ustroju sądów powszechnych (dalej powoływanej jako u.s.p.) ${ }^{25}$, art. 88 ust. 2 p.a., art. 80 ust. 3 prp.

Druga kwestia dotyczy zaostrzenia przez sądy dyscyplinarne drugiej instancji kar eliminacyjnych w postępowaniu odwoławczym. Przez pojęcie kary eliminacyjnej należy rozumieć karę wydalenia $\mathrm{z}$ adwokatury, czy pozbawienie prawa wykonywania zawodu radcy prawnego. Sąd drugiej instancji nie może zaostrzyć kary przez orzeczenie dożywotniego pozbawienia wolności. Jeżeli więc stosuje się do postępowania dyscyplinarnego przepisy kpk., to nie można orzec kary eliminacyjnej. Rozbieżność w orzecznictwie Sądu Najwyższego została rozstrzygnięta uchwałą Składu Siedmiu Sędziów z dnia 30 czerwca 2008 r. $^{26}$, w której Sąd Najwyższy stwierdził, że „ten przepis nie ma zastosowania do postępowań dyscyplinarnych”. Według Sądu Najwyższego, sąd odwoławczy może orzec karę pozbawienia wykonywania zawodu w sprawie karnej. Nie jest to objęte zakazem, zatem byłoby paradoksem, gdyby w sprawie karnej można by taką karę orzec, a w sprawie dyscyplinarnej nie można by jej zaostrzyć.

Odnosząc się do kwestii zaskarżania orzeczeń organów dyscyplinarnych do sądów powszechnych bądź Sądu Najwyższego, można więc wskazać na zatarcie siatki pojęciowej i zniekształcenie charakteru prawnego środków zaskarżenia przyjętych w procedurze karnej i cywilnej.

W przypadku ustawy z dnia 27 lipca 2005 r. Prawo o szkolnictwie wyższym (powoływanej dalej jako psw.) ${ }^{27}$ art. 146 ust. 4 stanowi, że od prawomocnego orzeczenia komisji dyscyplinarnej, o której mowa w art. 142 ust. 1 pkt 2, stronom służy odwołanie do Sądu Apelacyjnego w Warszawie - Sądu Pracy i Ubezpieczeń Społecznych. Do odwołania stosuje się przepisy kodeksu postępowania cywilnego dotyczące apelacji. Od orzeczenia sądu apelacyjnego nie służy skarga kasacyjna, lecz jak wskazuje się w komentarzach, istnieje możliwość wywiedzenia skargi do Sądu Najwyższego o stwierdzenie niezgodności z prawem prawomocnego orzeczenia Sądu Apelacyjnego w Warszawie ${ }^{28}$.

Ustawa o szkolnictwie wyższym nie określa podstaw odwołania, jednak, zgodnie $\mathrm{z}$ art. $368 \mathrm{kpc}$., odwołanie winno czynić zadość wymaganiom przewidzianym dla pisma procesowego, a ponadto zawierać oznaczenie wyroku, od którego jest wniesione, ze wskazaniem, czy jest on zaskarżony w całości czy w części; zwięzłe przedstawienie

\footnotetext{
24 I KZP 8/06, I OSKW 10/2006 poz. 87.

25 Ustawa z dnia 21 lipca 2001 r. Prawo o ustroju sądów powszechnych (tekst jedn. Dz.U. z 2015 r. poz. 133).

26 IKZP 11/08, OSNKW 2008 r. poz. 57.

27 Ustawa z dnia 27 lipca 2005 r. Prawo o szkolnictwie wyższym (tekst jedn. Dz.U. z 2016 r. poz. 1842).

28 H. Izdebski, Prawo o szkolnictwie wyższym. Komentarz. Wydanie II, Lex/el 2015.
} 
zarzutów i ich uzasadnienie; powołanie, w razie potrzeby, nowych faktów i dowodów oraz wykazanie, że ich powołanie w postępowaniu przed sądem pierwszej instancji nie było możliwe albo że potrzeba powołania się na nie wynikła później; oraz wniosek o zmianę lub o uchylenie wyroku z zaznaczeniem zakresu żądanej zmiany lub uchylenia.

W komentarzach do ustawy o szkolnictwie wyższym podkreśla się, że wykorzystanie odwołania prowadzi do przeniesienia sprawy ze środowiska akademickiego do niezależnej, niezawisłej i bezstronnej władzy sądowniczej i stwarza obwinionemu nauczycielowi akademickiemu możliwość skorzystania z konstytucyjnego prawa do sądu - stanowiącego jeden $\mathrm{z}$ fundamentów demokratycznego państwa prawnego ${ }^{29}$.

Należy zauważyć, że odpowiednie stosowanie przepisów o apelacji nakazywałoby stosować do prawomocnych orzeczeń walor suspensywny apelacji cywilnej, tj. wstrzymać wykonalność zaskarżonego orzeczenia. Jednak ust. 5 art. 146 psw. przewiduje, że informację o prawomocnym orzeczeniu w sprawach naruszeń, o których mowa w art. 144 ust. 3 pkt 1-5 (a więc w sprawach związanych z prawami autorskimi i badaniami naukowymi), komisja dyscyplinarna przekazuje do wiadomości organu przyznającego środki finansowe na naukę, czyli do ministra właściwego ds. nauki.

Tezę o braku suspensywności odwołania do Sądu Apelacyjnego w Warszawie potwierdza rozporządzenie Ministra Nauki i Szkolnictwa Wyższego z dnia 17 października 2014 r. w sprawie szczegółowego trybu postępowania wyjaśniającego i dyscyplinarnego prowadzonego wobec nauczycieli akademickich oraz sposobu wykonywania i zatarcia kar dyscyplinarnych ${ }^{30}$. Stanowi ono w $\$ 42$, że rektor niezwłocznie po otrzymaniu prawomocnego orzeczenia komisji dyscyplinarnej zarządza wykonanie orzeczonej kary dyscyplinarnej oraz umieszczenie odpisu orzeczenia w aktach osobowych nauczyciela akademickiego, a także doręczenie tego orzeczenia ministrowi i ministrowi nadzorującemu.

Ponadto, informację o ustaniu stosunku pracy w związku z ukaraniem karą dyscyplinarną pozbawienia prawa do wykonywania zawodu nauczyciela akademickiego na stałe zamieszcza się w świadectwie pracy nauczyciela akademickiego ( $\$ 43$ rozporządzenia). Dopiero zmiana przez Sąd Apelacyjny orzeczenia komisji dyscyplinarnej o pozbawieniu prawa do wykonywania zawodu nauczyciela akademickiego i orzeczenie innej, łagodniejszej kary dyscyplinarnej lub wyroku uniewinniającego oznacza, że odpadła podstawa stwierdzenia wygaśnięcia stosunku pracy i następuje jego restytucja, bez potrzeby składania przez pracodawcę oświadczenia woli. Nauczyciel akademicki ma zaś roszczenie o dopuszczenie do pracy ${ }^{31}$.

Zob. np. postanowienie SN z dnia 22 października 1999 r., I PKN 216/99, OSNAPiUS 2001, nr 5, poz. 165. P. Wajda, A. Wiktorowska (w:) Prawo o szkolnictwie wyższym. Komentarz, W. Sanetra, M. Wierzbowski (red.), Lex/el 2013.

30 Dz.U. z 2014 r. poz. 1430.

31 E. Ura (w:) Akademickie prawo pracy. Komentarz do art. 107-158 oraz 196-201a i 226 ustawy Prawo o szkolnictwie wyższym, K.W. Baran (red.) SN, Lex/El 2015 i podane tam orzecznictwo. 
Ewolucja wybranych procedur dyscyplinarnych w świetle konwencyjnego...

Wydaje się, że model zaskarżania orzeczeń organów dyscyplinarnych do sądów powszechnych zależy także od zaufania ustawodawcy do kwalifikacji prawniczych i prestiżu przedstawicieli danego zawodu prawniczego, w szczególności sędziów. Sądami dyscyplinarnymi pierwszej instancji w sprawach sędziów są właściwe miejscowo Sądy Apelacyjne, a sądem odwoławczym Sąd Najwyższy (art. 110 ust. 1 u.s.p.). W kwestiach proceduralnych należy wskazać na art. $121 \$ 1$ u.s.p. stanowiący, że od wydanych w pierwszej instancji wyroków sądu dyscyplinarnego oraz postanowień i zarządzeń zamykających drogę do wydania wyroku przysługuje odwołanie obwinionemu i rzecznikowi dyscyplinarnemu, a także Krajowej Radzie Sądownictwa i Ministrowi Sprawiedliwości.

Odwołanie powinno być rozpoznane w terminie dwóch miesięcy od dnia jego wpłynięcia do sądu dyscyplinarnego drugiej instancji (art. $121 \S 2$ u.s.p.). Do odwołania będą miały natomiast zastosowanie przepisy postępowania karnego co do formy i sposobu jego wniesienia. W szczególności odwołujący się powinien wskazać zaskarżone rozstrzygnięcie lub ustalenie, a także podać, czego się domaga. W komentarzach do art. 121 u.s.p. wskazywano, że mimo iż obwiniony sędzia jest z zasady wysoko wyspecjalizowanym prawnikiem, wydaje się, iż nie należy stosować do niego obowiązków spoczywających na rzeczniku dyscyplinarnym i obrońcy wynikających $\mathrm{z}$ art. $427 \$ 2 \mathrm{kpk}$., a polegających na wskazaniu zarzutów stawianych rozstrzygnięciu i sporządzeniu uzasadnienia odwołania. Zbytnie formalizowanie w tym zakresie mogłoby prowadzić do ograniczenia prawa do obrony ${ }^{32}$. Jednakże, jak wskazuje się w orzecznictwie Sądu Najwyższego, brak w odwołaniu nie tylko wskazania zakresu, w jakim zaskarża się rozstrzygnięcie sądu dyscyplinarnego pierwszej instancji, lecz także wniosków odwoławczych, a w istocie nawet zarzutów (art. $425 \$ 2$ i art. $433 \$ 1$ kpk.), utrudnia Sądowi Najwyższemu rozpoznanie „środka odwoławczego”33. Odwołujący się może również wskazać nowe fakty lub dowody, ale tylko wtedy, jeśli nie mógł ich powołać przed sądem pierwszej instancji (art. $427 \$ 3 \mathrm{kpk}$. w brzmieniu obowiązującym od 15 kwietnia 2016 r.).

Odwołanie co do winy uważa się za zwrócone przeciwko całości wyroku, a odwołanie co do kary uważa się za zwrócone przeciwko całości rozstrzygnięcia o karze i środkach karnych. W odwołaniu można podnosić zarzuty, które nie stanowiły lub nie mogły stanowić przedmiotu zażalenia (art. $447 \mathrm{kpk}$.). W związku z odpowiednim stosowaniem kpk. w postępowaniu dyscyplinarnym wobec sędziów należy uznać, że podstawami odwołania mogą być zarówno bezwzględne przyczyny odwoławcze $\mathrm{z}$ art. $439 \$ 1 \mathrm{kpk}$., jak i względne przyczyny z art. $438 \mathrm{kpk}$.

Sąd Najwyższy rozpoznaje sprawę w granicach odwołania (stanowiącego odpowiednik apelacji), a w zakresie szerszym o tyle, o ile ustawa to przewiduje ${ }^{34}$. Sąd Naj-

34 Wyrok SN z 29 czerwca 2007 r., SNO 37/07, OSNSD 2007, poz. 54. 
wyższy jest obowiązany rozważyć wszystkie wnioski i zarzuty wskazane w odwołaniu (art. 433 kpk.); może orzec na niekorzyść obwinionego tylko wtedy, gdy wniesiono na jego niekorzyść odwołanie, a także tylko w granicach zaskarżenia. Jeżeli odwołanie pochodzi od rzecznika dyscyplinarnego (Krajowej Rady Sądownictwa, Ministra Sprawiedliwości), Sąd Najwyższy może orzec na niekorzyść obwinionego ponadto tylko $\mathrm{w}$ razie stwierdzenia uchybień podniesionych w odwołaniu lub podlegających uwzględnieniu $\mathrm{z}$ urzędu. Odwołanie wniesione na niekorzyść obwinionego może spowodować orzeczenie także na jego korzyśćc $c^{35}$.

Sąd Najwyższy może ograniczyć rozpoznanie odwołania jedynie do poszczególnych uchybień podniesionych przez stronę lub podlegających uwzględnieniu $\mathrm{z}$ urzędu, jeżeli rozpoznanie $\mathrm{w}$ tym zakresie jest wystarczające do wydania orzeczenia, a rozpoznanie pozostałych uchybień byłoby przedwczesne lub bezprzedmiotowe dla dalszego toku postępowania (art. $436 \mathrm{kpk}$.).

\section{Wpływ reform postępowania karnego na modele postępowania dyscyplinarnego}

W niniejszym opracowaniu ograniczono się do dość kontrowersyjnej tezy, że tzw. wielka reforma przepisów kpk. z 1 lipca 2015 r. stosowanych jedynie odpowiednio do postępowań dyscyplinarnych nie wpłynęła zasadniczo na przebieg postępowania przed sądami dyscyplinarnymi (chociażby ze względu na krótki okres obowiązywania nowelizacji - do 15 kwietnia 2016 r.). Powyższy wniosek uzasadnia fakt, że w latach 2015-2016 nie nastąpiły żadne istotne zmiany dotyczące tych procedur, a w szczególności nie uwzględniono w nich zasady wzmocnionej kontradyktoryjności rozprawy głównej przewidzianej przez art. $167 \mathrm{kpk}$. w wersji z dnia 1 lipca 2015 r. Odnosząc się do problematyki niniejszego opracowania, za istotne należy uznać jedynie zmiany w obszarze zaskarżania orzeczeń sądów dyscyplinarnych do Sądu Najwyższego bądź w trybie kasacji bądź odwołania (odnośnie sędziów). Należy również wspomnieć o ograniczeniu odpowiedzialności dyscyplinarnej prokuratorów wynikającym z nowej ustawy o prokuraturze ${ }^{36}$.

W sferze karnoprocesowej trzeba wskazać na dwie różne płaszczyzny wpływu zmian procedury karnej dokonanych na przestrzeni lat 2013-2016 na postępowania dyscyplinarne. W przypadku postępowania dyscyplinarnego wobec sędziów wypada zauważyć utrzymanie przez nowelizację z dnia 15 kwietnia 2016 r. (a wprowadzonej od 1 lipca 2015 r.) zmiany art. $434 \$ 2$ kpk. Stanowi on, że środek odwoławczy wniesiony na niekorzyść oskarżonego może spowodować orzeczenie także na korzyść oskarżonego, jeżeli zachodzą przesłanki określone w art. 440 lub art. 455 kpk. Nie 
Ewolucja wybranych procedur dyscyplinarnych w świetle konwencyjnego...

można też pominąć instytucji tzw. względnej prekluzji dowodowej w postępowaniu odwoławczym, przewidzianej przez obowiązujący obecnie art. $427 \$ 3 \mathrm{kpk}$.

Ponadto, warto wskazać na zmienioną regulację art. $452 \mathrm{kpk}$. poszerzającą zakres postępowania dowodowego (w tym co do istoty sprawy - skreślenie art. $452 \$ 1$ kpk.) oraz ograniczenie możliwości zwrotu przez sąd odwoławczy sprawy do ponownego rozpoznania (art. $437 \$ 2 \mathrm{kpk}$.). Powyższe rozważania zasadniczo nie odnoszą się bezpośrednio do członków korporacji niebędących sędziami, którym przysługuje jedynie nadzwyczajny środek zaskarżenia w postaci kasacji do Sądu Najwyższego, a więc mogą być one stosowane w postępowaniach dyscyplinarnych jedynie odpowiednio, w zakresie przewidzianym przez art. $518 \mathrm{kpk}$.

Jeśli chodzi o uregulowanie odpowiedzialności dyscyplinarnej w nowej ustawie o prokuraturze z dnia 12 stycznia 2016 r. $^{37}$, to w kwestiach proceduralnych wypada wspomnieć, że art. 163 tejże ustawy przewiduje w $\$ 1$, iż od orzeczenia wydanego przez Odwoławczy Sąd Dyscyplinarny stronom i Prokuratorowi Generalnemu przysługuje kasacja do Sądu Najwyższego. Kasacja może być wniesiona z powodu rażącego naruszenia prawa lub rażącej niewspółmierności kary dyscyplinarnej. Termin do wniesienia kasacji wynosi dla strony - 30 dni, zaś dla Prokuratora Generalnego 3 miesiące od dnia doręczenia orzeczenia z uzasadnieniem, odpowiednio, stronie lub Prokuratorowi Generalnemu.

Strona wnosi kasację za pośrednictwem sądu dyscyplinarnego, który wydał zaskarżone orzeczenie, natomiast Prokurator Generalny wnosi kasację bezpośrednio do Sądu Najwyższego (art. $163 \$ 3$ i 4 u.p.). Sąd Najwyższy rozpoznaje kasację na rozprawie w składzie trzech sędziów (art. $163 \$ 5$ ustawy o prokuraturze).

Natomiast jako istotna jawi się w kontekście podstaw materialnoprawnych odpowiedzialności dyscyplinarnej prokuratorów regulacja art. 137 ust. 2 wspomnianej wyżej ustawy o prokuraturze z 2016 r. Przewiduje ona, że nie stanowi przewinienia dyscyplinarnego działanie lub zaniechanie prokuratora podjęte wyłącznie w interesie społecznym. Wydaje się, że ze względu na szeroki i nieostry zakres pojęcia „interesu społecznego", budzącego wiele kontrowersji w doktrynie, a którego rzecznikiem jest m.in. prokurator ${ }^{38}$, ten specyficzny kontratyp odpowiedzialności dyscyplinarnej może być interpretowany zbyt szeroko, prowadząc w rezultacie do osłabienia ochrony praw innych uczestników procesu karnego.

\footnotetext{
$37 \quad$ Dz.U. z 2016 r. poz. 177.

38 Na temat pojęcia interesu społecznego i roli prokuratora jako rzecznika interesu społecznego zob. L. Mazowiecka, Prokurator Generalny jako rzecznik interesu społecznego, (w:) System prawa karnego procesowego P. Hofmański (red.), t. VI, Strony i inni uczestnicy postępowania karnego, C. Kulesza (red.), Warszawa 2016, s. 1163-1186 i R.A.Stefański, Prokurator jako rzecznik interesu społecznego, Ibidem, s. 1189-1247 i podana tam literatura.
} 


\section{BIBLIOGRAFIA}

Akademickie prawo pracy. Komentarz do art. 107-158 oraz 196-201a i 226 ustawy - Prawo o szkolnictwie wyższym, K.W. Baran (red.), Lex/el 2015.

Bodnar A., Postępowania dyscyplinarne w wolnych zawodach prawniczych w kontekście orzecznictwa ETPC, (w:) Postępowania dyscyplinarne w zawodach prawniczych. Model ustrojowy i praktyka A. Bodnar, P. Kubaszewski (red.), Warszawa 2013.

Dudka K., Stosowanie przepisów kpk. w postępowaniu dyscyplinarnym w stosunku do nauczycieli akademickich, (w:) Węzłowe problemy procesu karnego P. Hofmański (red.), Warszawa 2010.

Izdebski H., Prawo o szkolnictwie wyższym. Komentarz, wydanie II, Lex/el 2015;

Kanty K., Kanty T., Komentarz do przepisów o postępowaniu dyscyplinarnym adwokatów, Warszawa Gdańsk 2013.

Kozielewicz W., Postępowania dyscyplinarne w wolnych zawodach prawniczych w praktyce orzeczniczej SN, (w:) Postępowania dyscyplinarne w zawodach prawniczych. Model ustrojowy i praktyka, A. Bodnar, P. Kubaszewski (red.), Warszawa 2013.

Mazowiecka L., Prokurator Generalny jako rzecznik interesu społecznego, (w:) System prawa karnego procesowego, Hofmański (red.), t. VI, Strony i inni uczestnicy postępowania karnego, C. Kulesza (red.), Warszawa 2016.

Prawo o szkolnictwie wyższym. Komentarz, W. Sanetra, M. Wierzbowski (red.), Lex/el 2013.

Prawo o ustroju sądów powszechnych. Komentarz, A. Górski (red.), Lex/el 2013.

Skuczyński P., Aktualne problemy odpowiedzialności dyscyplinarnej w zawodach prawniczych, (w:) Postępowania dyscyplinarne w zawodach prawniczych. Model ustrojowy i praktyka, A. Bodnar, P. Kubaszewski (red.), Warszawa 2013.

Stefański R.A., Prokurator jako rzecznik interesu społecznego, (w:) System prawa karnego procesowego, P. Hofmański (red.), t. VI Strony i inni uczestnicy postępowania karnego C. Kulesza (red.), Warszawa 2016. 